Stawomir Chrost*

Kielce

\title{
Pedagogiczne implikacje humanizmu personalistycznego Wincentego Granata
}

Intencją autora jest odpowiedź na pytanie: jakie są pedagogiczne konsekwencje humanizmu personalistycznego Wincentego Granata? Aby zrealizować to zamierzenie, autor odpowiada najpierw na pytania pomocnicze: kim był Wincenty Granat?; jak jest specyfika polskiego personalizmu?; jak Granat przedstawia człowieka?; jak jest charakterystyka pedagogiki chrześcijańskiego personalizmu?

\section{Doctor humanus - rys biograficzny Wincentego Granata ${ }^{1}$}

Sługa Boży ksiądz Wincenty Granat urodził się 1 kwietnia 1900 roku w Ćmielowie. Szkołę średnią (1914-1918) i studia seminaryjne (1918-1923)

* Ks. dr hab. Sławomir Chrost, prof. UJK, jest kierownikiem Zakładu Pracy Socjalnej i Integracji Społecznej w Instytucie Pedagogiki i Psychologii Uniwersytetu Jana Kochanowskiego w Kielcach. Adres: Instytut Pedagogiki i Psychologii UJK, ul. Krakowska 11, 25-029 Kielce; e-mail: schrost@op.pl.

${ }^{1}$ Por. Halina I. Szumił, Przez prawdę do miłości. Stuga Boży ks. Wincenty Granat (1900-1979) (Sandomierz: WDS, 2010); Halina I. Szumił, „Ksiądz Wincenty Granat. Nauczyciel chrześcijańskiej doktryny i jej realizator (1900-1979)", w: Chrześcijanie, t. XI, red. Bohdan Bejze (Warszawa: ATK, 1983), 9-32. 
ukończył w Sandomierzu. W 1923 roku podjął studia specjalistyczne na Papieskim Uniwersytecie Gregoriańskim w Rzymie, które ukończył, uzyskując stopień doktora filozofii (1925) i teologii (1928). W czasie studiów, 24 sierpnia 1924 roku, w katedrze sandomierskiej przyjął święcenia kapłańskie. Po powrocie do kraju pełnił w Radomiu funkcję prefekta szkół powszechnych i średnich (1928-1933). Następnie wykładał przedmioty filozoficzne oraz teologię dogmatyczną (1933-1958) w Wyższym Seminarium Duchownym w Sandomierzu. W 1952 roku związał się z Katolickim Uniwersytetem Lubelskim (KUL), gdzie był kierownikiem Katedry Teologii Dogmatycznej, Fundamentalnej i Porównawczej. Piastował stanowisko prodziekana Wydziału Teologii KUL (1956-1958) oraz rektora tej uczelni (1965-1970). W 1970 roku zrezygnował z funkcji rektora KUL-u i przeniósł się do Opola Lubelskiego, w którym kontynuował działalność pisarską i duszpasterską. W 1977 roku powrócił do Sandomierza, gdzie zmarł w opinii świętości 11 grudnia 1979 roku i został pochowany na grzebalnym cmentarzu katedralnym.

Czesław Bartnik uważa, że Wincenty Granat był jednym z twórców tak zwanego polskiego personalizmu. Uczeń ks. Wincentego Granata, ks. Wacław Hryniewicz, wymownie określił swego Mistrza tytułem: Doctor Humanus - Doktor Ludzki. Nadto stwierdził, że pozostał on „do końca teologiem, który potrafił łączyć żarliwość i siłę swoich przekonań teologicznych z autentyczną pokorą umysłu i wewnętrzną prawością ducha. Taki Mistrz uczy nawet wtedy, gdy zabraknie go już pośród żyjących"².

\section{Specyfika personalizmu polskiego}

Podstawowym wyznacznikiem personalizmu (od łacińskiego personaosoba) jest twierdzenie, że człowiek jest najpierw osobą, zanim przypisze się mu określone cechy bądź właściwości. „Bycie osobą” jest faktem pierwotnym i nieredukowalnym, a jego uwzględnienie stanowi warunek sine qua non uprawiania jakiejkolwiek humanistyki. Bogusław Śliwerski twierdzi, że:

Z personalistycznego spojrzenia na człowieka w procesie socjalizacji i wychowania wynikają: jego afirmacja jako wartości podstawowej i autotelicznej, prymat życia duchowego, nieredukowalność osoby do rzeczy, ciała, zmysłów i potrzeb biologicznych, niezbywalność praw tkwiących w naturze ludzkiej,

2 Wacław Hryniewicz, „Doctor humanus”, Studia Sandomierskie 2 (1981): 35-40. 
świadomość powinności obec innych opartej na zasadach sprawiedliwości oraz odrzucenie anarchicznej koncepcji wolności osoby³.

Stefan Kunowski, prowadząc refleksję nad korzeniami personalizmu, zauważa, że w XIX wieku rozpoczęła się rewolucja obyczajowa będąca uzewnętrznieniem zwyrodniałego ustroju kapitalistycznego. Wyrażała się ona w stosowaniu techniki antykoncepcyjnej, w przerywaniu ciąży, w sterylizacji, w sztucznym zapładnianiu kobiet itp. Aby zapobiec tej sytuacji, nie wystarczały już prawa państwowe, lecz coraz potrzebniejsza stawała się jakaś rewolucja moralna. Ruch teoretyczny, rozwijający się szczególnie w XX wieku, który miał uzasadnić pojawiające się procesy moralizmu, ich potrzebę i konieczność, jak też wyłożyć ich treści wychowawcze, doprowadził do wyłonienia się różnego rodzaju personalizmów ${ }^{4}$.

Czesław Bartnik twierdzi, że badania nad szczegółowym charakterem myśli polskiej ujawniają że jej dominantą jest taki system treściowy i metodyczny, który można nazwać ogólnie personalizmem 5 . Rozwiajli go między innymi: Bronisław Trentowski, Karol Libelt, Cyprian Kamil Norwid, Stanisław Wyspiański, Wincenty Granat. Bartnik w następujacych słowach pisze o specyfice polskiego personalizmu:

Personalizm polski, kształtujący się bardzo głeboko i szeroko w kulturze polskiej, siega niewątpliwie do samej Ewangelii, a następnie do augustynizmu, tomizmu i różnych innych wzniosłych kierunków antropologii, ale posiada też cechy typowo polskie. Są nimi: przekonanie o nieskończonej wartości człowieka, poczucie godności osoby, mocno zarysowana indywidualność osobista, wysoki ładunek emocji ludzkich, idea obywatelskiego współrządzenia Narodem i Państwem, uwyraźnienie podmiotowości w religii i Kościele oraz ogromne wyczulenie na wolność osobistą i społeczną ${ }^{6}$.

W centrum personalizmu polskiego znajduje się antropologia personalistyczna rozwijana szczególnie przez Wincentego Granata, Stefana Świeżawskiego czy Mieczysława Gogacza. W jej ramach rozważany jest człowiek jako osoba, jego natura, struktury, historia, życie wspólne, jaźń, życie ducho-

${ }^{3}$ Bogusław Śliwerski, Pedagogika ogólna (Kraków: Impuls, 2012), 273.

${ }^{4}$ Stefan Kunowski, Problematyka współczesnych systemów wychowania (Kraków: Impuls, 2000), 13, 62 .

5 Czesław Bartnik, Personalizm (Lublin: KUL, 2000), 152.

${ }^{6}$ Tamże, 153. 
we, idee humanistyczne. Osoba ludzka jest w pracach większości polskich personalistów (a szczególnie daje się to zauważyć w pracach Wincentego Granata) otwarta na Transcendencję. Według Bartnika, osoba stawała się ogniskową perspektywy, z której patrzyło się na człowieka i jego życie. Uważano ją za najwyższą tajemnicę bytu. Jest ona „czymś“, albo lepiej „kimś“, absolutnym; jest głównym centrum spotkania immanencji z transcendencją i stanowi odwzorowanie Jezusa Chrystusa: Człowieka i Boga. Człowiek jest częścią tego świata, naturą ludzką, ale i zarazem osobą, stanowiącą jakiś szczególny świat bytu w sobie, jakąś meta-naturę. Człowiek zatem jest procesem przekształcania się natury cielesno-duchowej w osobę jako najwyższą postać bytu, obrazem Trójcy Świętej. Osoba tkwi wewnątrz świata, wyrasta zeń i żyje w nim, ale również przekracza świat, otwiera się na rzeczywistość nieskończenie wyższą i dąży do spełnienia się przez historię w przyszłości. Osoba jest szczytem rzeczywistości stworzonej, będąc jednocześnie odniesiona do osób Bożych?

\section{Specyficum humanum według Wincentego Granata}

Jedną z prób odpowiedzi na pytanie: kim jest człowiek?, jest religijna wizja osoby ludzkiej. Zawiera się ona w tak zwanej antropologii teologicznej. Wincenty Granat wśród specyficznych trudności nauki o człowieku wymienia: ograniczoność spojrzenia, niebezpieczeństwo „zamknięcia się” w „schemacie” i nazbyt szybkich uogólnieńn ${ }^{8}$. Autor ten wskazuje na potrzebę uprawiania antropologii teologicznej wiedząc, iż synteza podawana przez teologię katolicką nie jest wcale rozstrzygnięciem czy nawet wyjaśnieniem wszystkich problemów ludzkich, ponieważ: po pierwsze, ogranicza się do kwestii metafizycznych i religijno-moralnych; po wtóre, ciagle powraca do myśli o tajemniczości człowieka; po trzecie, operuje pojęciami łaski i grzechu, czyli zahacza o tajemnicę Boga, dobrowolną decyzję człowieka i jakieś siły wymykające się spod naukowych uogólnień9.

Personalizm chrześcijański dla Granata to wizja rzeczywistości, która podkreśla centralną w niej rolę człowieka - z woli Bożej (motyw teologiczny) i ze względu na jego wyjątkowość bytową (motyw filozoficzno-nau-

7 Tamże, 153-154.

${ }^{8}$ Wincenty Granat, Ku czlowiekowi i Bogu w Chrystusie, t. I (Lublin: KUL, 1972), $78-82$.

9 Tamże, 82. 
kowy). Swoje idee dotyczące człowieka zawarł Granat głównie w trylogii: Osoba ludzka. Próba definicji (pierwsze wyd. Sandomierz 1961, drugie wyd. poszerzone Lublin 2006), U podstaw humanizmu chrześcijańskiego (pierwsze wyd. Poznań 1976, drugie wydanie z nadtytułem Fenomen czlowieka, Lublin 2007), Personalizm chrześcijański (Poznań 1984). Natomiast idee humanizmu chrześcijańskiego Granat rozbudował w dwutomowej dogmatyce: Ku człowiekowi i Bogu w Chrystusie (Lublin 1972-1974).

Założenia światopoglądu personalistycznego Granata ${ }^{10}$ są następujące: realizm ontologiczny i teoriopoznawczy, pluralizm ontologiczny, uznanie substancjalnej tożsamości człowieka, możliwość poznania obiektywnej prawdy, a także aksjologia uznająca prymat prawdy wśród innych wartości. Podsumowując myśl personalistyczną Granata, Stanisław Kowalczyk stwierdził, że światopogląd personalistyczny omawianego autora jest interesującym ogniwem w dziejach myśli filozoficzno-teologicznej, doskonale łączącym augustynizm, tomizm ze współczesnymi kierunkami myślowymi.

Osoba ludzka, według Granata, jest integralną rzeczywistością cielesno-duchową, subsystentną, mającą duszę nieśmiertelną i ponadhistoryczne przeznaczenie. Tym, co jest swoiście wyakcentowane w personalistycznych ujęciach Granta, to rozróżnienie opisu osoby i opisu osobowości. Granat dla uporządkowania terminologii proponuje odróżnianie pojęć „osoby” i „osobowości". Gdy wyodrębniamy różne sfery działań danego podmiotu, czyli gdy próbujemy na człowieka patrzeć aspektowo, będziemy mówić o osobowości. Na tej podstawie można wyszczególnić osobowość psychiczną, osobowość etyczną, osobowość społeczną, itd. Wszystkie te partykularne opisy osoby spełniają swoją olbrzymią rolę w pedagogice, etyce, psychologii, socjologii, itp. W odniesieniu zaś do opisu łącznie wszystkich istotnych cech człowieka, mającego na celu wyjaśnienie jego egzystencji, będziemy posługiwać się terminem osoba, a mówiąc jeszcze precyzyjniej: osoba integralna. To tutaj Granat wskazuje na jednostkową całość osoby ludzkiej, a wśród jej najbardziej istotnych cech największy akcent kładzie na jej odrębność, samoistność, wolność, autonomię oraz autoteleologię ${ }^{11}$.

Osoba stanowi podstawę metafizyczną jedności wszystkich cech stanowiących byt człowieka i nie może być utożsamiona ani z jaźnią, ani z wolą, ani też z ciałem czy charakterem społecznym człowieka. Zdaniem Granata, psychologia, etyka i socjologia - jako nauki empiryczne - docierają przy po-

${ }^{10}$ Wincenty Granat, Fenomen człowieka. U podstaw humanizmu chrześcijańskiego (Lublin: KUL, 2007); Wincenty Granat, Osoba ludzka. Próba definicji (Lublin: KUL, 2006).

${ }^{11}$ Wincenty Granat, Personalizm chrześcijański (Poznań: KŚW, 1984), 68-70. 
mocy sobie właściwych metod jedynie do opisu osobowości. Opisują więc kolejno: „osobowość psychiczną”, „osobowość etyczną” i „osobowość społeczną”. „Osobowość” oznacza fundamentalne cechy działaniowe osoby, na których koncentrują się poszczególne nauki empiryczne: świadomość „ja”, wolność w relacji do wartości, relacyjność i byt społeczny osoby. Granat pokazuje, że osoba jest podstawą metafizyczną dla tych wielkości, jest tajemnica, która ujawnia się (objawia) w dynamice każdej osoby na drodze jej samorealizacji i tworzenia kultury. Owa dynamika osoby domaga się przyjęcia niezmiennego fundamentu ontologicznego oraz cech istotnych, poprzez realizację których człowiek realizuje się jako osoba. Personalizm integralny jest właśnie konsekwencją w miarę integralnej definicji osoby ${ }^{12}$.

Granat, podejmując się próby opisu osoby, stwierdza: „Osoba ludzka to jednostkowy, indywidualny, substancjalny, cielesno-duchowy podmiot zdolny działać w sposób rozumny, dobrowolny, moralny i społeczny, w celu harmonijnego ubogacania siebie i innych ludzi w zakresie kultury"13. Osoba, według Granata, ma swoją wieloraką odrębność, fizyczną, psychiczną, psychiczno-duchowa, ujawniającą się w charakterze i temperamencie oraz szeroko pojętym stylu życia. Osoba ma swoją odrębność jako centrum (do którego zmierzają bodźce zewnętrzne) i jako aktywny punkt wyjścia (ku światu i innym ludziom). Osoba stanowi empiryczną odrębność i niezłączalność $\mathrm{z}$ inną rzeczywistością ${ }^{14}$.

Granat uważa, że termin „osoba chrześcijańska” wskazuje na trwanie nie tylko doczesne, ale wiekuiste. Według niego, definicja osoby ludzkiej w ujęciu chrześcijańskim powinna zawierać nie tylko stwierdzenie, że jest ona podmiotem cielesno-duchowym, ale także przybranym Synem Bożym oraz działa rozumnie i dobrowolnie, współpracując z Chrystusem Odkupicielem ${ }^{15}$. Według Granata, kiedy mówimy o naturze czy nadnaturze chrześcijańskiej, to zgodnie $\mathrm{z}$ wiarą uznajemy w niej nowy rodzaj życia. Można powiedzieć, że życie nadprzyrodzone to miłość z jej warunkami (wiara i nadzieja), z jej konsekwencjami (uczestnictwo w Miłości Najdoskonalszej) i przymiotami (wiekuista trwałość, obcowanie z całym światem dobra) ${ }^{16}$. „Kim więc jest człowiek-chrześcijanin? - pyta Granat i daje odpowiedź - Jest istotą ciele-

\footnotetext{
12 Granat, Osoba, 22.

${ }^{13}$ Granat, Personalizm, 79-80.

14 Granat, Osoba, 244.

15 Granat, Fenomen, 393.

16 Tamże, 409-411.
} 
sno-duchową, społeczną, tworzącą kulturę i dzieckiem Bożym, dążącym do wiekuistego życia i uczestniczenia w życiu Osób Bożych"17.

Bycie osobą to wartość naczelna, dająca początek całej plejadzie wartości wyrażających się we współbyciu z ludźmi, ale także i z Bogiem. Osoba ludzka to podmiot, który może być przez samego Boga dopuszczony do uczestnictwa w jego życiu ${ }^{18}$. Nowy chrześcijański człowiek to człowiek wiary, poprzez którą łączy się z Chrystusem - jego życie pozostaje zgodne z Ewangelią.

W personalistycznym humanizmie chrześcijańskim Granata da się zaobserwować coś, co można umownie nazwać paralelizmem antropo-teistycznym. Według niego, Bóg w centrum swego zainteresowania stawia człowieka, a tenże ma się jedynie odwzajemnić odniesieniem całej swej doczesności do Transcendencji. Stawianie równocześnie i Boga i człowieka w centrum zainteresowania nie jest wewnętrznie sprzeczne. Te rzeczywistości dopełniają się. Krzysztof Guzowski twierdzi, że „Granat łączy wyraźnie humanizm wcielenia $\mathrm{z}$ humanizmem odkupienia, pokazując, że Bóg w całym swym działaniu wobec człowieka jest jego miłośnikiem, tj. pierwszym humanistą"19.

Granat broni tezy o bytowej samoistności, odrębności i autonomii człowieka; broni idei osoby i jej godności. Uważa, że człowiek ma, co prawda, świadomość praw przyrody i psychiki, ale równocześnie jest przekonany, że posiada swój wewnętrzny rezerwat, w którym jest władcą jedynym, a jego działanie tworzy samą istotę wolnej woli, mianowicie jej aktywność i autodeterminizm. Granat podkreśla, że:

Człowieka nie da się zredukować do żadnej wielkości, w której by zanikała jego odrębność; nawet w zjednoczeniu z Bogiem czy to w życiu doczesnym, czy wiekuistym, człowiek zachowuje swą osobowość, a więc pluralizm bytowy jest tu radykalny, to nie znaczy, że człowiek nie jest pod względem fizycznobiologicznym cząstką przyrody i że jest od niej wyizolowany. Człowiek jest zależny od środowiska materialnego, w którym żyje, ale ponad nie wyrasta przez swą myśl, przez sumienie i moralność, przez swą twórczość kulturalną i przez osobowy związek z Bogiem ${ }^{20}$.

17 Tamże, 413.

18 Marian Puchała, Kulturotwórczy wymiar chrześcijaństwa jako motyw jego wiarygodności (Wincenty Granat) (Poznań: UAM, 2002), 26-27.

${ }^{19}$ Krzysztof Guzowski, „Nowość humanizmu chrześcijańskiego”, w: Wincenty Granat, Fenomen człowieka. U podstaw humanizmu chrześcijańskiego (Lublin: KUL, 2007), 7.

${ }^{20}$ Granat, Fenomen, 362. 
Wolność jest swoistym fundamentem osoby. Człowiek jest istotą duchową i rozumną, w której owa wolność ma swe metafizyczne zakorzenienie. Granat twierdzi, że wolność jest pojęciem wieloznacznym. Mówi o wolności politycznej, gospodarczej, prawnej, wolności mowy, sumienia, wolności prasy, zgromadzeń, podkreślając, że wspólnym mianownikiem tych różnych odmian wolności jest „niezależność w działaniu”21.

Granat powtarza, że wolna wola jest życiowym postulatem ${ }^{22}$ :

Wolność woli tak ściśle łączy się ze strukturą osoby integralnej i osobowości etycznej, że nie da się o nich pomyśleć bez tego przymiotu; po prostu personalizm szczególnie w integralnym ujęciu, bez idei wolnej woli i odpowiedzialności, byłby pustym frazesem. Wolność woli - pisze dalej Granat - jest największym przywilejem człowieka i decyduje o jego wielkości i godności; wynosi ona człowieka ponad cały wszechświat materialny, daje uczestnictwo w wolności samego Boga, tworzy z człowieka odrębną i niepowtarzalną jednostkę. Dzięki wolności człowiek może tworzyć sam siebie i ustawicznie doskonalić, zgodnie z ideałem, jaki sobie postawił, dzięki wolności człowiek może stać się nowym stworzeniem $(\mathrm{Ga} 6,15)^{23}$.

Zrezygnowanie z idei wolnej woli kwestionowałoby sens takich pojęć, jak dobro i zło. Pociągałoby za sobą odrzucenie świata wartości moralnych. Człowiek musiałby podporządkować się fatalizmowi, zejść na poziom biologicznej konieczności. Granat podkreśla doniosłość świadomości wolnej woli w życiu człowieka i w tejże świadomości poszukuje źródeł humanistycznego optymizmu. Znamienne pozostająjego słowa, w których podkreśla, że: „Dla człowieka mającego świadomość wolnej woli nigdy właściwie nie istnieje przegrana, dopóki jeszcze znajduje się on na ziemi. [...] A gdy chodzi o prawa rozwoju moralnego, to może im nie być posłuszny i nie iść po równej linii ku doskonałości, lecz psuć porządek moralny, ale także go naprawiać" ${ }^{24}$.

\footnotetext{
${ }^{21}$ Granat, Osoba, 226-229.

22 Tamże, 255-258.

23 Tamże, 258.

${ }^{24}$ Tamże, 231.
} 


\section{Pedagogika chrześcijańskiego humanizmu}

Zanim przedstwione zostaną pedagogiczne konsekwencje myśli antropologicznej Wincentego Granata, warto zatrzymać się nad odpowiedzią na pytanie: jaka jest charakterystyka pedagogiki personalistycznej o inspiracji chrześcijańskiej?

Pedagogika personalistyczna o inspiracji chrześcijańskiej sięga w swojej genezie do grecko-rzymskiej tradycji filozoficznej. W tym nurcie pedagogiki personalistycznej eksponuje się osobę ludzką jako podmiot zaangażowany w proces socjalizacji, kształcenia i wychowania. Afirmuje się godność, rozumność, wolność, zdolność do miłości każdej osoby, bowiem każdy podmiot osobowy posiada w sobie walor niepowtarzalny i nadrzędny wobec wszystkich wartości materialnych, ekonomicznych i społeczno-politycznych ${ }^{25}$.

Marian Nowak uważa, że w personalizmie uprzywilejowane miejsce zajmuje myślenie egzystencjalne i antropologiczne, a poprzez to także pedagogiczne. Personalizm przyjmuje bowiem postawę otwarcia na egzystencję, ujmowaną w wymiarze przestrzenno-czasowym. Eksponuje także wątek porzucenia statycznej koncepcji osoby i skierowania ku dynamicznym determinantom życia osobowego ${ }^{26}$. W następujących słowach podsumowuje tenże autor istotę pedagogiki personalistycznej:

Pedagogika personalistyczna jest jednym z ważnych nurtów współczesnej refleksji pedagogicznej. Płaszczyznę odniesienia dla tego kierunku stanowi koncepcja świata i człowieka, która przyjmuje wzajemną zależność od siebie takich elementów, jak względny indeterminizm, wolność, transcendencja. $\mathrm{Na}$ płaszczyźnie epistemologicznej pedagogika personalistyczna jawi się jako koncepcja wychowania oparta na teorii poznania, rozważająca różne stopnie poznania przy przyjęciu, jako zasady, podstawowej jednorodności poznania ludzkiego, zdolnego dociekać prawdy ${ }^{27}$.

Wychowanie w pedagogice personalistycznej ma przede wszystkim charakter spotkania osób, którym przysługuje ta sama godność. Z racji, iż

${ }_{25}$ Marian Nowak, „O pedagogikę wrażliwą na osobę i na wspólnoty osób”, Roczniki Nauk Społecznych 2 (1996): 31-51.

${ }^{26}$ Marian Nowak, „Pedagogika personalistyczna”, w: Pedagogika, t. 1, red. Zbigniew Kwieciński, Bogusław Śliwerski (Warszawa: PWN, 2006), 232.

27 Tamże, 246. 
spotkanie to dokonuje się w konkretnej rzeczywistości, zadaniem pedagogiki personalistycznej jest więc ujawnianie podstawowego sensu wychowania w konkretnych uwarunkowaniach historycznych, społecznych, politycznych i kulturowych.

Podstawowe założenia pedagogiki personalistycznej streszczają się w następujących twierdzeniach:

a) wychowanie jest ważnym czynnikiem promowania wszechstronnie pojmowanego dobra osoby;

b) jednym $\mathrm{z}$ celów wychowania jest uzdalnianie osoby do przejęcia kierownictwa nad własnym procesem rozwoju;

c) wychowanie powinno prowadzić do tego, aby wychowanek uświadomił sobie w pełni fakt bycia osoba;

d) proces wychowania spoczywa przede wszystkim w rękach wychowanka; wychowawca spełnia rolę pomocniczą;

e) zagrożenia dla wychowania płyną z naturalizmu, indywidualizmu czy liberalizmu;

f) istnieje związek między nauczaniem a wychowaniem;

g) rodzina stanowi stanowi nadrzędne i najbardziej wartościowe środowisko wychowawcze;

h) istnieje wpływ czynnika nadprzyrodzonego (wiara i łaska) w wychowaniu ${ }^{28}$.

Według Mariana Nowaka, z trzech czynników wychowania (czynniki wrodzone - endogenne, czynniki zewnętrzne - egzogenne i czynniki osobowościowe - duchowe) to właśnie czynniki duchowe dominują w definicjach znanych z opracowań personalistycznych (m.in. definicje wychowania K. Schallera, Jana Pawła II, J. Tarnowskiego). Ani naturalny rozwój, ani odpowiednie uwarunkowania zewnętrzne, ale własna aktywność duchowa jest istotnym, z punktu widzenia pedagogiki chrześcijańskiej o inspiracji personalistycznej, czynnikiem w wychowaniu, co sprawia, że proces wychowania człowieka nie może być sprowadzony tylko do spraw genetycznych czy też wpływów uwarunkowań zewnętrznych ${ }^{29}$.

Bogusław Śliwerski, omawiając wychowanie jako formację duchowa, zauważa, że personalizm zakłada, iż wartość i godność człowieka tkwią

${ }^{28}$ Marian Nowak, „Ku nowej edukacji zorientowanej na osobę”, w: Pedagogika alternatywna - dylematy teorii i praktyki, red. Bogusław Śliwerski (Kraków: Impuls, 1998), 29-42.

${ }^{29}$ Marian Nowak, „Osoba i wartość w pedagogice ogólnej”, w: Antropologiczna pedagogika ogólna, red. Marian Nowak, Piotr Magier, Iwona Szewczak (Lublin: KUL, 2010), 52-53. 
w nim samym, dlatego też osoba ludzka jest wartością funadamentalną i autoteliczną. Personalizm chrześcijański określa egzystencję człowieka w odniesieniu do innych ludzi, ale przede wszystkim poprzez relację z Bogiem ${ }^{30}$.

Stefan Kunowski podkreśla natomiast, że tylko personalizm chrześcijański jest uniwersalny. Wyraża to w następujących słowach: „z reguły kierunki personalizmu przedstawiają człowieka tylko częściowo i jednostronnie, a swoje zasady rozciagają w zasadzie na pewne grupy społeczne, jedynie personalizm chrześcijański z racji swego uniwersalizmu obejmuje całego człowieka i odnosi się do wszystkich ludzi"31.

Barbara Kiereś twierdzi, że na kanwie filozofii i teologii możemy mówić o pedagogice chrześcijańskiej i pedagogice personalistycznej. Obie operują pojęciem osoby, ale w jednej (chrześcijańskiej) osoba ma wymiar teologiczny (związku człowieka z Bogiem), druga (personalistyczna) wskazuje na życie rozumne (możność i aktualizacja). Personalizm chrześcijański jest ściśle powiązany z religijną wizją człowieka i ma swe źródło w chrześcijańskim Objawieniu $^{32}$. Istotnymi czynnikami wyróżniającymi wychowanie w kulturze chrześcijańskiej są:

a) uznanie bezwzględnie celu ostatecznego - zjednoczenia z Bogiem;

b) swoista droga do celu - naśladowanie Chrystusa i usprawnianie się w czynnej miłości;

c) swoiste środki wychowawcze - takie jak liturgia i sakramenty ${ }^{33}$.

Wychowanie chrześcijańskie rozwijające się w ciagu 2000 lat stało się, według Stefana Kunowskiego, podstawą tradycji wychowania europejskiego w ogóle. Jego podstawą światopoglądową jest religia objawiona w pełni przez Jezusa Chrystusa. Reguluje ona stosunek osobowy człowieka do Boga na podstawie wiary jako rozumnego posłuszeństwa prawdom ogłoszonym przez Boga. Wychowanie chrześcijańskie oparte jest na dogmatach (trynitarnym, o stworzeniu, o odkupieniu, o uświęceniu, o sądzie za dobre lub złe życie, o zmartwychwstaniu ciał i życiu wiecznym). Ma ono charakter teo-, Chrysto- i eklezjocentryczny. Osią centralną jest tu łaska Boża, wysłużona przez Chrystusa i udzielana przez Ducha Świętego, polegająca na dopusz-

30 Śliwerski, Pedagogika, 272.

${ }^{31}$ Kunowski, Problematyka, 63.

32 Barbara Kiereś, „Podstawy antropologiczne pedagogiki personalistycznej”, w: Antropologiczna pedagogika ogólna, red. Marian Nowak, Piotr Magier, Iwona Szewczak (Lublin: KUL, 2010), 100.

33 Tamże, 100-101. 
czeniu człowieka do udziału w życiu nadprzyrodzonym ${ }^{34}$. Wszystkie te idee kierownicze występują, według Kunowskiego, w wychowaniu katolickim w postaci Chrystocentryzmu, z którego wynikają moralizm, personalizm i humanizm chrześcijański ${ }^{35}$.

$\mathrm{Na}$ fundamencie personalizmu rozwinęła się chrześcijańska pedagogika personalistyczna, zwana także pedagogiką chrześcijańską ${ }^{36}$. Pedagogika chrześcijańska jest przykładem refleksji naukowej nad rzeczywistością wychowania, uwzględniającej treści płynące z Objawienia Bożego i rozwoju wychowawczej myśli Kościoła. Wywodzi swoją specyfikę i odrębność z przesłanek światopoglądowych, filozoficznych, teologicznych, religijnych. Jest postrzegana jako dyscyplina pedagogiczna, która znajduje się pod wpływem i w duchowym klimacie religii chrześcijańskiej ${ }^{37}$. Inspiracja chrześcijańska w pedagogice nie stawia siebie wyżej od innych orientacji czy koncepcji. Jej najbardziej narzucającą się przewagą może być fakt dwa tysiące lat liczącej tradycji wychowania w miłości do człowieka i w ukazywaniu ojcostwa Boga $^{38}$. Chrześcijańska orientacja $\mathrm{w}$ pedagogice powiązana jest z pewną hierarchią wartości i norm, a inspiracja przejawia się w zaangażowaniu chrześcijan w działalność wychowawczą.

\section{Pedagogiczne implikacje myśli Wincentego Granata}

Po przeanalizowaniu krótkiego biogramu Wincentego Granata i jego myśli antropologicznej oraz uwzględnieniu specyfiki personalizmu polskiego i pedagogiki personalistycznej o inspiracji chrześcijańskiej przyszedł czas na odpowiedź na zasadnicze pytanie: jakie są konsekwencje humanizmu personalistycznego Wincentego Granata dla pedagogiki?

Janina Kostkiewicz twierdzi, że propozycję Granata dotyczącą pedagogiki można zrekonstruować jako czterowymiarową koncepcję wychowania religijnego wywiedzioną z dogmatu katolickiego i zakorzenioną w tomizmie.

34 Stefan Kunowski, Podstawy wspótczesnej pedagogiki (Warszawa: Wydawnictwo Salezjańskie, 1993), 94-95.

35 Tamże, 98.

${ }^{36}$ Marian Nowak, „Pedagogika chrześcijańska: jej podstawy, rozwój i aktualny stan”, Rocznik Pedagogiczny 27 (2004): 46.

${ }^{37}$ Marian Nowak, Podstawy pedagogiki otwartej. Ujęcie dynamiczne w inspiracji chrześcijańskiej (Lublin: KUL, 1999), 82-89.

38 Tamże, 32-33. 
Pierwszy wymiar dotyczy źródeł teorii pedagogicznej. Są nimi prawdy wiary zawarte w Objawieniu chrześcijańskim - Biblii i Tradycji Kościoła. Drugi to założenia antropologiczno-metafizyczne. Mamy tu na myśli postulaty: personalizmu, łaski Bożej, uniwersalizmu, wychowania narodowego. Trzeci wymiar stanowią instytucje wychowujące. Według Granata są nimi: rodzina, Kościół, państwo. Czwartym wymiarem są wreszcie cele wychownia oraz główne zasady wychowania katolickiego. Dotykamy tu kwestii fundamentalnej, czyli wiecznego uczestnictwa w życiu Bożym oraz metod i środków do osiągniecia założonego celu, czyli zasad: aktualizacji, przygotowania ucznia do zmienności życia ${ }^{39}$.

Wincenty Granat, chociaż nie odbył studiów pedagogicznych, to jednak przez całe dorosłe życie poświęcał się wychowaniu młodego pokolenia jako prefekt szkolny i nauczyciel akademicki. Pedagogika w wymiarze praktycznym stanowiła zatem ważną część jego życia. Może dlatego Granat - chociaż rozwijał głównie myśl teologiczną - nawiązywał często w swoich pracach do teoretycznych refleksji nad wychowaniem $i$ kształceniem dzieci i młodzieży. W jego publikacjach można odnaleźć także odniesienia do pracy stricte pedagogicznej. Pisze między innymi takie słowa: „Pedagog zajmuje się warunkami i metodami kształcenia osobowości, a więc głównie uwzględnia jej aktywność, autonomię, plastyczność, zdolność wartościowania"40. Granat łączy proces wychowania z rozwojem osobowości człowieka. Możemy więc mówić o czterech filarach działalności pedagogicznej: aktywności, autonomii, plastyczności oraz zdolności do wartościowania. Aktywność wiąże się ściśle z miłością, autonomia z wolnością, plastyczność ze zdolnością do przemiany życia, a zdolność do wartościowania z prawdą.

Sprawą kluczową w wychowaniu (teorii wychowania) jest określenie tak zwanego ideału wychowania. Granat uważa, że istotą ideału wychowania jest miłość. Miłość jest najważniejsza w chrześcijaństwie i miłość winna stanowić klucz do zrozumienia wychowania w duchu chrześcijańskim. Pisze między innymi:

Miłość jest źródłem wszystkich wartości humanistycznych, miłość chrześcijańska pojęta autentycznie nie przekreśla żadnych wartości ludzkich, nawet przeciętnych, ale podnosi je przynajmniej niekiedy do wyżyn heroizmu. [...] Czy da się pomyśleć wyższy od miłości ideał życia ludzkiego? Zawiera ona w sobie

39 Janina Kostkiewicz, Kierunki i koncepcje pedagogiki katolickiej w Polsce 1918-1939 (Kraków: Impuls, 2013), 133-145.

${ }^{40}$ Granat, Fenomen, 391. 
po prostu aprobatę istnienia i postulat rozwoju człowieka, w jej zaś treści głębokiej istnieje udzielanie się dobra i jego przyjmowanie, a także wzajemność relacji osobowych. Z miłości autentycznej jest wykluczany egoizm, bo on zawsze dzieli, a ona łączy. Ideał miłości jest bardzo ludzki, bo branie i udzielanie jest głównym budulcem struktury psychicznej i moralnej człowieka. Miłość chrześcijańska, aprobując wszystkie wartości czysto ludzkie, mówi o udzielaniu się Boga ludziom i daniu im przywileju synostwa i obietnicy wiekuistego życia w obcowaniu z Osobami Boskimi ${ }^{41}$.

Według Granata, istotą katolickiego ideału wychowania jest miłość tworząca $^{42}$. Opiera się to na wierze, że Bóg jest Miłością, a opatrzność Jego, kierując światem, daje człowiekowi sposobność do kształcenia w sobie tej miłości, której zasiew w duszy ludzkiej jest pragnieniem Boga i od Niego pochodzi ${ }^{43}$.

Wychowanie do wolności, według Granata, jest podstawą osobowości autonomicznej. Bóg z miłości stworzył człowieka, obdarzając go wolnością. Dlatego Doctor Humanus uważa, że w jakimś zakresie człowiek jest wewnętrznie wolny. Wszystkie rodzaje wolności, jak polityczna, społeczna, gospodarcza, religijna, mają związek z tą najbardziej fundamentalną, jaką jest wewnętrzna wolność człowieka, będąca najwyższym boskim przywilejem, a równocześnie zagrożeniem. Mimo różnorakich determinizmów utrzymuje się ciagle w ludziach świadomość, że człowiek jest odpowiedzialny za swe czyny, że można go wynagradzać lub karać ${ }^{44}$. Wychowanie człowieka wolnego do odpowiedzialności, do wyboru coraz większego dobra, do podejmowania wolnych, trudnych decyzji, do niejako przekraczania siebie, swoich ograniczeń, staje się wyzwaniem dla wychowania.

Wychowanie do wolności jest, według Granata, nierozerwalnie związane z wychowaniem chrześcijańskim:

Człowiek w zasadzie, będąc psychicznie wolnym, w wielu wypadkach jest tak słaby, że ulega naciskowi środowiska i jego opinii, idzie chętnie za tym, co wydaje się przyjemniejsze, chociaż moralnie złe, ulega łatwo różnorakim egoizmom. Wolność zaś chrześcijańska polega na tym, że człowiek ma większą

41 Tamże, 182.

${ }^{42}$ Wincenty Granat, „Katolicki ideał wychowawczy”, Miesięcznik Katechetyczny $i$ Wychowawczy 10 (1936): 435-443.

43 Tamże, 435.

${ }^{44}$ Granat, Fenomen, 396. 
siłę opowiedzenia się za dobrem, że znajduje w sobie odwagę przeciwstawienia się ludzkim opiniom, że posiada wewnętrzną siłę do kierowania sobą ${ }^{45}$.

Człowiek, według Granata, jest i nieustannie się staje. „Chrześcijanin więc ma ustawicznie wzrastać w miłości, to jest ustawicznie się stawać; można o nim powiedzieć, że jest, a równocześnie, że ciągle się tworzy, idąc ku Chrystusowi, a przez Niego ku Bogu"46.

Przemiana, zdolność do przemiany świadczy o plastyczności osobowości. Dążenie do świętości, do doskonałości jest zadaniem wychowania. Człowiek stworzony na obraz i podobieństwo Boże, bytowo będący istotą uformowana, $\mathrm{w}$ aspekcie działaniowym, dynamicznym, jako istota niedoskonała, jest niejako wezwany do wprowadzania ciagle dobrych zmian w swoje życie.

Bardzo ważną rolą pedagoga jest, według Granata, rozwijanie w osobowości wychowanka zdolności właściwego wartościowania. Ta natomiast powiązana jest z właściwym odczytywaniem prawdy Bożej, która stanowi miarę i kryterium postępowania ludzkiego. Umiejętne odczytywanie prawdy Bożej, a nie tworzenie prawdy, jest cechą wyróżniającą chrześcijanina. Umiejętność życia w prawdzie Bożej i prawdzie o sobie jest zadaniem wychowania chrześcijańskiego. Granat pisze: „Obok prawd naturalnych formułowanych przez nasz umysł, i tych, które Chrystus głosił jako prawdy religijno-moralne, istnieje jeszcze prawda i fałsz życia i na to On zwracał uwagę czasem w formie dość ostrej. Fałsz życia, tj. obłuda, rozkłada strukturę moralną człowieka" ${ }^{47}$. Doctor Humanus akcentuje potrzebę oparcia etyki i wychowania moralnego człowieka na prawdzie mającej swoje źródło w Bogu. Ocenianie czynów ludzkich według kryteriów zapisanych w naturze człowieka przez Boga, potępianie obłudy i w związku z tym kładzenie nacisku na wewnętrzne życie człowieka jest wzorem dla tego rodzaju etyki ${ }^{48}$.

Myślą spajającą humanizm personalistyczny Granata w odniesieniu do pedagogiki jest to, że wychowanie jest przygotowaniem nie tylko do życia, ale i do śmierci. Ten element wydaje się być najcenniejszy dla współczesnej pedagogiki, która często nie wykracza poza „ramy doczesności”. Człowiek bowiem jest osobą i ma cel realizujący się w wieczności. Pełna personaliza-

\footnotetext{
45 Tamże, 397.

46 Tamże, 346.

47 Tamże, 183.

48 Tamże, 184.
} 
cja wspólnoty ludzkiej, według sandomierskiego uczonego, może nastąpić dopiero w życiu wiecznym. Granat pisze:

Humanizm chrześcijański jest personalistyczny, ponieważ zawiera się w nim pogląd, że ku osobie ludzkiej tzn. jej ubogaceniu i rozwojowi powinny być skierowane wszystkie dążenia społeczne; jest ona celem, a nie narzędziem. Ponadto w chrześcijańskiej wierze istnieje przekonanie, że ludzie zbawieni mają uczestniczyć w życiu osób Bożych; nastąpi w czasach eschatologicznych pełna personalizacja wspólnoty ludzkiej ${ }^{49}$.

Według Granata personalizm katolicki w pedagogice:

będzie mocno podkreślał wychowanie humanistyczne i rozwój samodzielności, będzie wymagał indywidualnego traktowania wychowanków, będzie rozbudzał poczucie odpowiedzialności i honoru. To przekonanie, że człowiek jest nie tylko członkiem narodu, państwa, Kościoła, ale przede wszystkim jest osobą i ma cel realizujący się w wieczności, musi uczuciowo zrosnąć się z psychiką wychowanka ${ }^{50}$.

Głównym celem wychowania katolickiego, według Granata, jest wieczne uczestnictwo w życiu Bożym ludzi odkupionych przez Chrystusa. Drogą do tego celu jest Chrystus. Kształtowanie Chrystusa w człowieku oznacza uznawać, uszlachetniać i uaktywniać wszelkie posiadane przez niego siły natury. Pociaga to za sobą także zharmonizowanie sił natury przy wsparciu łaski uświęcającej i kierowanie ich do dalszej współpracy z Chrystusem dla rozwoju i doskonalenia siebie oraz wspólnoty ${ }^{51}$.

\section{Podsumowanie}

Wincenty Granat reprezentował nurt personalizmu chrześcijańskiego, ukazujący centralną rolę człowieka ze względu na wolę Bożą (motyw teologiczny) i wyjątkowość bytową (motyw filozoficzny). W personalistycznym humanizmie chrześcijańskim Granata da się zaobserwować coś, co można

49 Tamże, 417.

${ }^{50}$ Wincenty Granat, ,Zasady pedagogii katolickiej w świetle dogmatu Odkupienia i grzechu pierworodnego", Miesięcznik Katechetyczny i Wychowawczy 1-2 (1939), 32-33.

51 Tamże, 51-52. 
umownie nazwać paralelizmem antropo-teistycznym, gdzie Bóg w centrum swego zainteresowania stawia człowieka, a tenże ma się jedynie odwzajemnić odniesieniem całej swej doczesności do Transcendencji. Ma to swoje konsekwencje pedagogiczne. Pedagog zajmuje się warunkami i metodami kształcenia osobowości, a więc głównie uwzględnia jej aktywność (miłość), autonomię (wolność), plastyczność (przemiana), zdolność wartościowania (prawda). Według Granata personalizm katolicki w pedagogice akcentuje wychowanie humanistyczne i rozwój samodzielności, wymaga indywidualnego traktowania wychowanków, rozbudza poczucie odpowiedzialności i honoru. Ale rzeczą najważniejszą jest przekonanie, że człowiek to nie tylko członek narodu, państwa, Kościoła, ale przede wszystkim osoba i ma cel realizujący się w wieczności.

\section{Pedagogical Implications of Vincent Granat's Personalistic Humanism (Summary)}

The Servant of God Father. prof. Wincenty Granat was one of the representatives of the Christian personalism mainstream, showing the central role of the human due to the will of God (theological theme) and the ontological uniqueness (philosophical theme). In Granat's personalist Christian humanism one can observe something that can be conventionally called anthropological-theistic parallelism, where God poses a human in the center of His interest, and the selfsame has only to repay all its temporal reference to the Transcendent. This has some educational consequences. An educator deals with the conditions and methods of personality education, and therefore mainly takes into account its activity (love), autonomy (freedom), plasticity (transformation), and capacity of evaluation (true). According to Granat the Catholic personalism in education will strongly emphasize the humanistic education and the development of self-reliance, will require individual treatment to pupils, and will stimulate sense of responsibility and honour. The belief that a man is not only a member of the nation, the state, the Church, but above all he/she is a person and has an aim to achieve in eternity, must emotionally grow into the ward's psyche.

Key words: personalistic Christian humanism education; anthropological-theistic parallelism. 


\section{Pedagogiczne implikacje humanizmu personalistycznego Wincentego Granata (Streszczenie)}

Sługa Boży ks. prof. Wincenty Granat reprezentował nurt personalizmu chrześcijańskiego, ukazujący centralną rolę człowieka ze względu na wolę Bożą (motyw teologiczny) i wyjątkowość bytową (motyw filozoficzny). W personalistycznym humanizmie chrześcijańskim Granata da się zaobserwować coś, co można umownie nazwać paralelizmem antropo-teistycznym, gdzie Bóg w centrum swego zainteresowania stawia człowieka, a tenże ma się jedynie odwzajemnić odniesieniem całej swej doczesności do Transcendencji. Ma to swoje konsekwencje pedagogiczne. Pedagog zajmuje się warunkami i metodami kształcenia osobowości, a więc głównie uwzględnia jej aktywność (miłość), autonomię (wolność), plastyczność (przemiana), zdolność wartościowania (prawda). Według Granata personalizm katolicki w pedagogice będzie mocno podkreślał wychowanie humanistyczne i rozwój samodzielności, będzie wymagał indywidualnego traktowania wychowanków, będzie rozbudzał poczucie odpowiedzialności i honoru. To przekonanie, że człowiek jest nie tylko członkiem narodu, państwa, Kościoła, ale przede wszystkim jest osobą i ma cel realizujący się w wieczności, musi uczuciowo zrosnąć się z psychiką wychowanka.

Słowa kluczowe: pedagogika personalistycznego humanizmu chrześcijańskiego; paralelizm antropo-teistyczny.

\section{Bibliografia}

Bartnik, Czesław. Personalizm. Lublin: KUL, 2000.

Granat, Wincenty. Fenomen czlowieka. U podstaw humanizmu chrześcijańskiego. Lublin: KUL, 2007.

Granat, Wincenty. „Katolicki ideał wychowawczy”. Miesięcznik Katechetyczny i Wychowawczy 10 (1936): 435-443.

Granat, Wincenty. Ku czlowiekowi i Bogu w Chrystusie, t. I. Lublin: KUL, 1972.

Granat, Wincenty. Osoba ludzka. Próba definicji. Lublin: KUL, 2006.

Granat, Wincenty. Personalizm chrześcijański. Poznań: KŚW, 1985.

Granat, Wincenty. „Zasady pedagogii katolickiej w świetle dogmatu Odkupienia i grzechu pierworodnego". Miesięcznik Katechetyczny i Wychowawczy 1-2 (1939): 26-53. 
Guzowski, Krzysztof. „Nowość humanizmu chrześcijańskiego”. W: Wincenty Granat, Fenomen człowieka. U podstaw humanizmu chrześcijańskiego, 5-10. Lublin: KUL, 2007.

Hryniewicz, Wacław. „Doctor humanus”. Studia Sandomierskie 2 (1981): 35-40.

Kiereś, Barbara. „Podstawy antropologiczne pedagogiki personalistycznej”. W: Antropologiczna pedagogika ogólna, red. Marian Nowak, Piotr Magier, Iwona Szewczak, 95-102. Lublin: KUL, 2010.

Kostkiewicz, Janina. Kierunki i koncepcje pedagogiki katolickiej w Polsce 1918-1939. Kraków: Impuls, 2013.

Kunowski, Stefan. Podstawy współczesnej pedagogiki. Warszawa: Wydawnictwo Salezjańskie, 1993.

Kunowski, Stefan. Problematyka wspótczesnych systemów wychowania. Kraków: Impuls, 2000.

Nowak, Marian. „Ku nowej edukacji zorientowanej na osobę”. W: Pedagogika alternatywna - dylematy teorii i praktyki, red. Bogusław Śliwerski, 29-42. Kraków: Impuls, 1998.

Nowak, Marian. „O pedagogikę wrażliwą na osobę i na wspólnoty osób”. Roczniki Nauk Społecznych 2 (1996): 31-51.

Nowak, Marian. „Osoba i wartość w pedagogice ogólnej”. W: Antropologiczna pedagogika ogólna, red. Marian Nowak, Piotr Magier, Iwona Szewczak, 41-56. Lublin: KUL, 2010.

Nowak, Marian. „Pedagogika chrześcijańska: jej podstawy, rozwój i aktualny stan”. Rocznik Pedagogiczny 27 (2004): 37-58.

Nowak, Marian. „Pedagogika personalistyczna”. W: Pedagogika, t. 1, red. Zbigniew Kwieciński, Bogusław Śliwerski, 232-247. Warszawa: PWN, 2006.

Nowak, Marian. Podstawy pedagogiki otwartej. Ujęcie dynamiczne w inspiracji chrześcijańskiej. Lublin: KUL, 1999.

Puchała, Marek. Kulturotwórczy wymiar chrześcijaństwa jako motyw jego wiarygodności (Wincenty Granat). Poznań: UAM, 2002.

Szumił, Halina. „Ksiądz Wincenty Granat. Nauczyciel chrześcijańskiej doktryny i jej realizator (1900-1979)". W: Chrześcijanie, t. XI, red. Bohdan Bejze, 9-32. Warszawa: ATK 1983.

Szumił, Halina. Przez prawdę do miłości. Stuga Boży ks. Wincenty Granat (1900-1979). Sandomierz: WDS, 2010.

Śliwerski, Bogusław. Pedagogika ogólna. Kraków: Impuls, 2012. 
